\title{
Toxicological Impact of Leachates from Lemna Refuse Dump Site on African Catfish (Clarias gariepinus, Burchell 1882) Fingerlings Under Laboratory Condition
}

\author{
Udeme Uyom Udofia ${ }^{1}$, Finian Tobias Okoro ${ }^{1}$ and Akaninyene Paul Joseph ${ }^{{ }^{*}}$ \\ ${ }^{1}$ Department of Zoology and Environmental Biology, Faculty of Biological Sciences, University of \\ Calabar, Calabar, Nigeria.
}

Authors' contributions

This work was carried out in collaboration among all authors. Author FTO designed the study, performed the statistical analysis, wrote the protocol, and wrote the first draft of the manuscript. Authors UUU and APJ managed the analyses of the study. Author APJ managed the literature searches. All authors read and approved the final manuscript.

Article Information

DOI: $10.9734 / A R R B / 2021 / v 36 i 730396$ Editor(s):

(1) Dr. Bechan Sharma, University of Allahabad, India. Reviewers:

(1) Lanka Undugoda, University of Sri Jayewardenepura, Sri Lanka.

(2) Tadesu Hailu Mengesha, Wolkite University, Ethiopia. Complete Peer review History: https://www.sdiarticle4.com/review-history/71258

Original Research Article

Received 06 May 2021

Accepted 12 July 2021

Published 14 July 2021

\section{ABSTRACT}

Aim: The study investigated the toxicological effects of Calabar municipal dumpsite leachate on the fingerlings of Clarias gariepinus.

Experimental Design: The study was set-up in a $6 \times 2$ Complete Randomized Block Design.

Methodology: During the studt 120 C. gariepinus fingerlings were used. Each group was made up of 10 fingerlings. The fingerlings were exposed to $0 \%$ (control group), $15 \%, 20 \%, 25 \%, 30 \%$ and $35 \%$ of leachate in duplicate. Histopathology was also carried-out on the gills and liver of the fingerlings of each exposure group.

Results: The temperature, $\mathrm{pH}$, conductivity, and BOD increased with increasing leachate concentration, while the DO decreased with concentration. $5.17 \pm 0.66 \mathrm{~cm}$ and $1.09 \pm 0.40 \mathrm{~g}$ mean length and weight respectively of fingerlings were determined. Mortality depended on concentration. The 96 hours $L^{2} C_{50}$ value with $95 \%$ confidence limit of C. gariepinus fingerlings exposed to leachate 
was $22.5 \% \pm 0.89$, and was significant with a determination coefficient $\left(r^{2}\right)$ of 0.93 at $P<0.05$. Leachates altered the orientation of gills and liver of the fingerlings.

Conclusion and Recommendations: The low $\mathrm{LC}_{50}$ value of fingerlings exposed to different concentrations of leachate indicates a high toxicity of the leachate and altered the gills and liver of fingerlings. To this end, we recommended dumpsites are sited at a distance far from water bodies and areas inhabited by human, to mitigate the leeching of leachate into nearby aquatic systems. Law against indiscriminate discharge of waste into drainage channels and any aquatic system should be enforced by Government, to prevent mortality of biological organisms, extinction of species, contamination of organisms in nearby aquatic systems, changes in the physical properties, and health risk to humans that depends on resources from these aquatic systems for food.

Keywords: Toxicity; leachate; Calabar Municipal; Refuse dump; Clarias gariepinus; Fingerlings.

\section{INTRODUCTION}

Leachate is described as the water-based solution of compounds from solid wastes dumped in landfills [1]. Leachate can also be defined as any liquid that when it flow through substances, carry materials such as suspended solids, solutes, or other substances through which it flows through, adding contaminants of public concern to the environment [1]. Landfills maybe acted upon by infiltration from precipitation or groundwater underflow. Water passes through the waste, carries organic and inorganic substances, and eventually aggregate at the landfill bottom. The contaminated liquid is referred to as 'leachate' and can permeate through soil [2].

Leachates are known to contain a variety of naturally forming and anthropogenic chemicals which may be toxic to a wide variety of organisms. They take up organic and inorganic constituents and thus contains high concentration of organic and inorganic ions, including heavy metals [2]. Leachate consist of a range of compounds, which can enter into the environment, especially close water bodies [1]. Leachate also contains microbes, capable of causing public health implications [1]. Christensen et al. [1] described landfill leachate as a combination of four groups of contaminants namely: heavy metals, xenobiotic organic compounds, dissolved organic matter, and inorganic macro-components. Other compounds in trace quantity are: arsenic, boron, lithium, selenium, and cobalt [2].

Worldwide, Landfilling is the main method used in the disposal of municipal solid waste. When underground water or precipitation water passes through disposed waste in a landfill, leachate is generated [3]. This liquid passes through the waste and extracts contaminants such as heavy metals, colloids, pathogens, inorganic, organic, and various contaminated substances [4]. Unevaporated and unabsorbed liquid flows out and downward, moving contaminants from within the landfill. The Contents of leachate depends to a great extent on the landfilling technology, waste age, and waste composition of the landfills, [5]. The substances disposed in a landfill gives the characteristic of the leachate produced. The composition of solid waste, waste age, precipitation rates, landfill design, and operation determines the toxic contaminants in a leachate [6].

In Nigeria, lack of proper management of solid waste has resulted in major environmental issues as leachate's main route of entry into the environment is through the waste disposal site. Designated dump sites are inadequate and waste are often disposed-off in uncontrolled public places. Annual generation of municipal solid waste are estimated at $29.78 \times 10^{9} \mathrm{~kg}$ and this is likely to increase due to population growth and urbanisation [7]. Organism such fish, green algae, bacteria, and other organisms were previously used by researchers as indicators of landfill leachate toxicity [8]. Also, biological organisms such as Geophagus brasiliensis, Artemia sp., Allium cepa, and Daphnia magnna have been used to determine the toxicity of abandoned landfill leachate [9]. The aim of the study was to determine the toxicological impacts of leachate from Lemna dump site on the fingerlings of $C$. gariepinus

\section{MATERIALS AND METHODS}

\subsection{Study Area}

Lemna dumpsite (Plate 1) is the major dumpsite in Calabar Municipality Local Government Area, Cross River State. Geographically, the dumpsite is approximately sited at longitude $008^{\circ} 22^{\prime} 12.7^{\prime \prime}$ $\mathrm{N}$ and latitude $005^{\circ} 02^{\prime} 02.6^{\prime \prime} \mathrm{E}$ (Fig 1). The dump 
site is about eleven (11) miles from the City Centre of Calabar. It is sited at Ikot Effanga Mkpa, off Murtala Mohammed High Way, close to North West filling station along Lemna construction company road. The dump site is flanked with a steep valley at the sides and slopes directly into Ikot Effanga Mkpa stream which is about $100 \mathrm{~m}$ from the dump site. The activities of this area are mainly the collection of plastics and tins by scavengers, who sells them to companies where they are recycled or reused.

\subsection{Collection and Transportation gariepinus}

C. gariepinus fingerlings were bought from the (Hatchery) of University of Calabar fish farm and placed into plastic buckets, then transfered to the Zoology and Environmental Biology, Post Graduate laboratory, University of Calabar.

\subsection{Acclimation and Maintenance of Study Organisms}

The fingerlings were allowed to acclimate to laboratory conditions for two weeks. During this time, they were fed at $4 \%$ of their body weight twice daily (8am and 9am) with commercial fish feed (coppen). Feeding was discontinued 48 hours to the experiment proper.

\subsection{Leachate Collection}

C. Small plastic bowl was used to collect the leachate by scooping the drained waste water into a 25 litres rubber, then preserved in an ice chest and transported immediately to the Post Graduate Laboratory of the Department of Zoology and Environmental Biology, University of Calabar for the experiment.

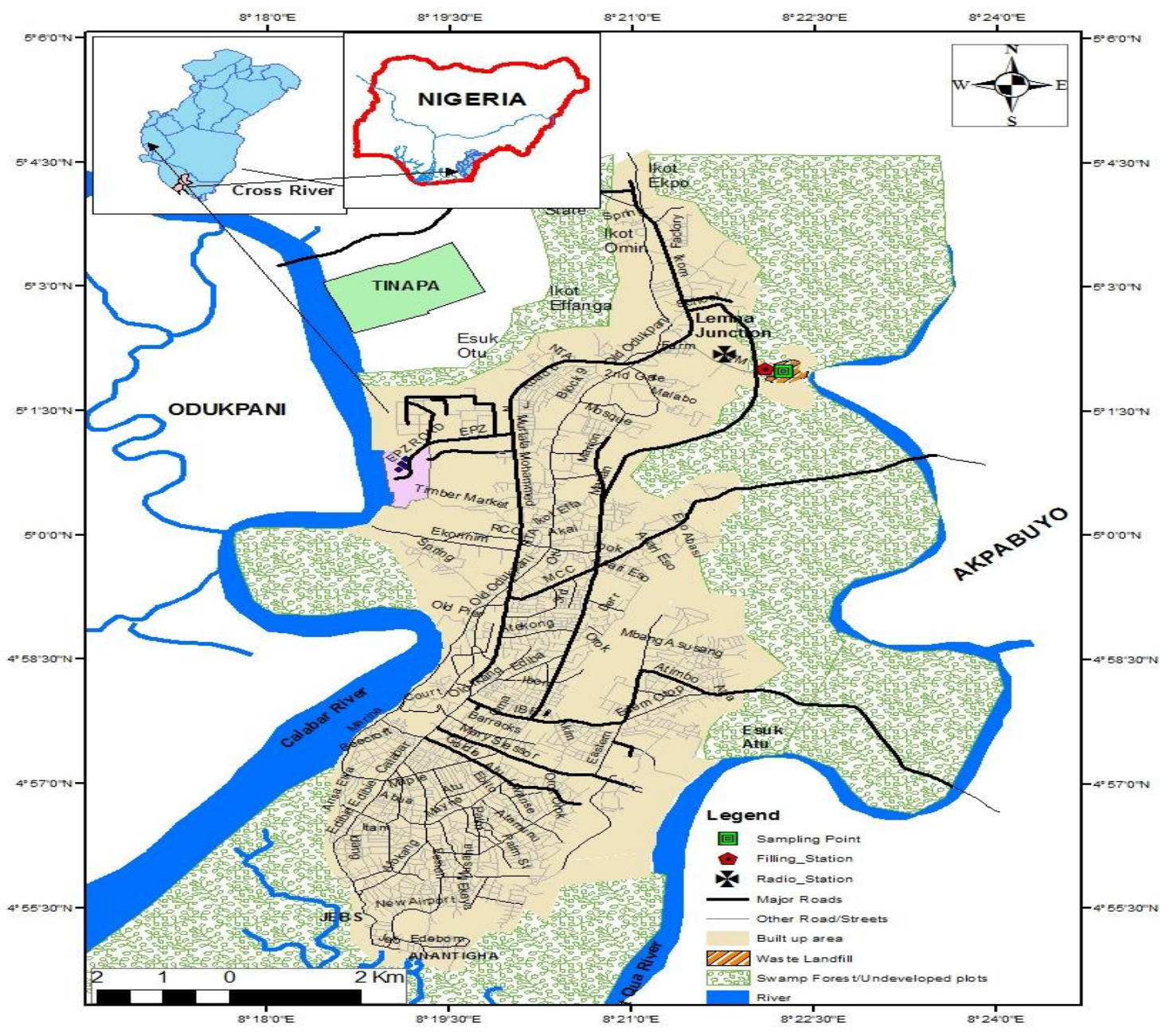

Fig. 1. Map of Calabar Municipality showing lemna dumpsite 


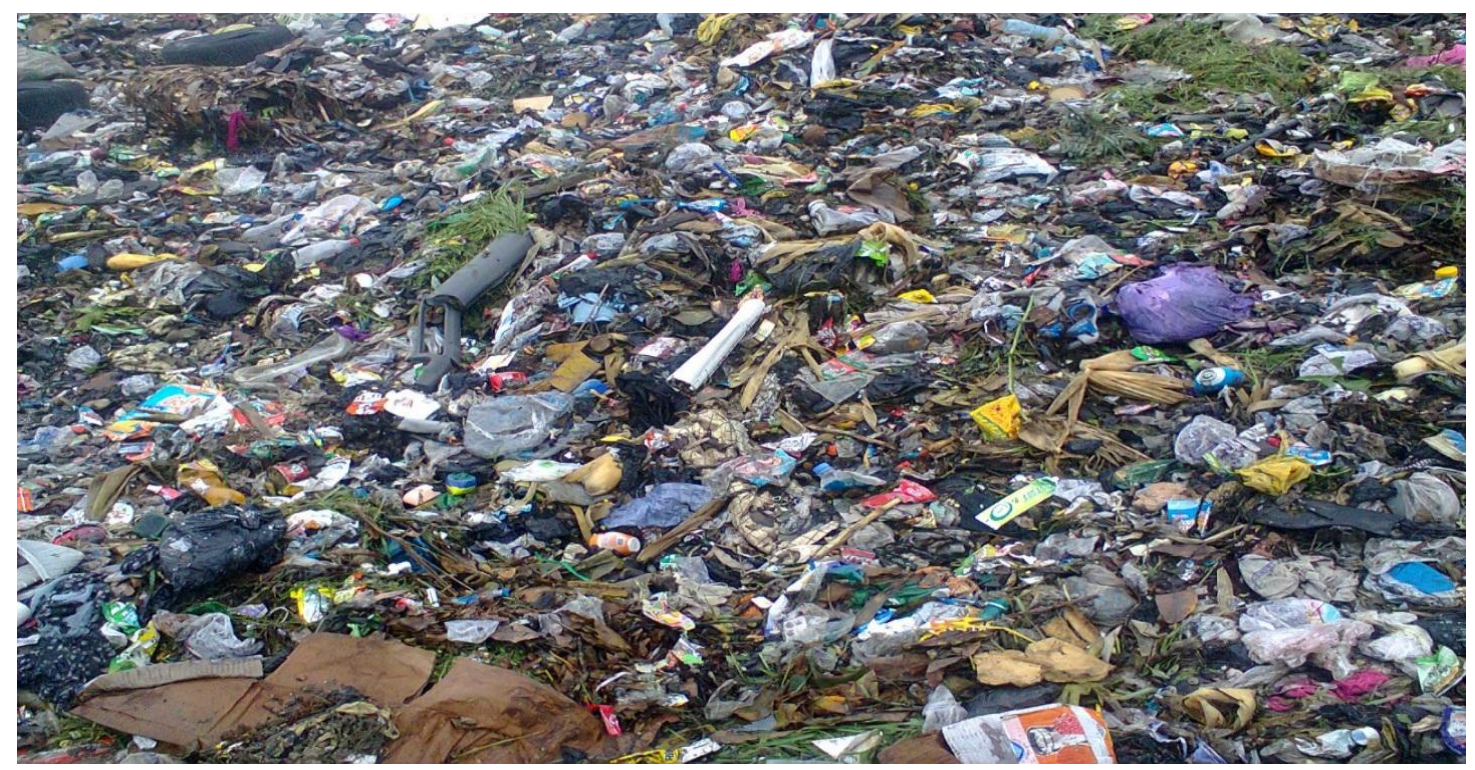

Plate 1. Lemna refuse dump site, Calabar Municipality, Cross River State, Nigeria

\subsection{Composition of Leachate}

The leachate was also collected into a one (1) litre plastic container, then preserved in an ice chest, before transporting to the Institute of Oceanography Laboratory, University of Calabar for leachate composition determination. The leachates will be analysed for the following parameters:

\subsubsection{Total organic carbon (\%)}

In the laboratory, the total organic carbon (TOC) was determined using a high quality total organic carbon analysers (Shimadzu, TOC-1000e) in percentage $(\%)$.

\subsubsection{Fatty acid (\%)}

High performance liquid chromatography was used to measure the fatty acid. Analysis and isolation of fatty acid was carried out using silica gel as described by Christie and Han [10].

\subsubsection{Ammonical nitrogen (\%)}

Nessler's reagent method was used to determine the ammonical nitrogen as described by Phansi et al. [11]. In the laboratory, the ammonia was added to mercury (11) iodide and potassium iodine to form a yellow solution. A camera was used to the capture the colour image which were used to analyse for determination of ammonia using the Image-J program.

\subsubsection{Oxidase (\%)}

The oxidase was determined using the principle of enzymatic oxidation of glucose in the presence of glucose oxidase. This was done as described by Trinder [12].

\subsubsection{Heavy metals}

In the laboratory, the leachate samples were allowed to normalise and assume the normal temperature of the laboratory. About $5 \mathrm{~mL}$ of the leachate were digested with $3 \mathrm{~mL}$ of concentrated hydrochloric acid. The samples were then heated in a steam bath for about 30 minutes and then allowed to cool. Then $50 \mathrm{~mL}$ of distilled water was added to the sample digest. The resulting digest was then analysed for iron $(\mathrm{Fe})$, manganese $(\mathrm{Mn})$, lead $(\mathrm{Pb})$, nickel $(\mathrm{Ni})$, and zinc ( $\mathrm{Zn})$ using the atomic absorption spectrophotometer (model AA-6800, Japan) in $\mathrm{mg} / \mathrm{kg}$ [13].

\subsection{Pre-testing}

Pre-testing was done using five concentration groups and the control with ten fingerlings of $C$. gariepinus in each aquarium. This was carried out to ascertain appropriate range of concentrations. The concentrations were arranged at logarithmic intervals to allow for total mortality within $96 \mathrm{hrs}$ at the utmost concentration and zero mortality within $96 \mathrm{hrs}$ of experiment, with intermediate at least two 
concentrations representing partial mortality. This method facilitates probit transformation of mortality data.

\subsection{Experimental Procedures, Morphometric Measurement, and Acute Toxicity Testing}

Ten Fingerlings selected at random were measured. The length in centimeters $(\mathrm{cm})$ and weight in grams $(\mathrm{g})$ were measured using measuring board and sensitive weighing balance respectively. The experiment was performed at the temperatures range between $27{ }^{\circ} \mathrm{C}-28{ }^{\circ} \mathrm{C}$ using a $60 \times 30 \times 30 \mathrm{~cm}^{3}$ aquaria in a $6 \times 2$ complete randomized block design. A total of 12 aquaria were used throughout the experiment and the leachate concentration added in duplicates. Five concentrations of the leachate were maintained for the study (i.e $15 \%, 20 \%$, $25 \%, 30 \%$, and $35 \%)$ as well as the control $(0 \%)$. Borehole water were used both as culture water and dilution of leachate. The fingerlings were introduced into $1000 \mathrm{~mL}$ of culture water containing different concentrations of leachate. As described by Rahman et al. [14], each test medium contained a total of 10 fingerlings with grand total of 20 fingerlings per group. A total of 120 fingerlings of $C$. gariepinus were used. The fingerlings introduction time into the different test concentrations were noted and their mortality recorded after 24, 48, 72, and 96 hours. Death of fingerlings were ascertained when they lie without motion at the base of the aquarium and responseless to prodding.

\subsection{Determination of $\mathrm{LC}_{50}$}

The dead Fingerlings were noted and the time of their death recorded in a tabular form as described by Sprague [15]. The lethal concentration $\left(\mathrm{LC}_{50}\right)$ of leachate on C. gariepinus fingerlings was calculated using the obtained data. Probit analysis was used to compute the 96 hrs LC ${ }_{50}$. Also, 95\% confidence limit and intervals were calculated $[16,17]$.

\subsection{Physico-chemical Parameters}

After 96 hrs, the physical parameters of the culture water in each test aquaria were monitored. The culture water was monitored insitu for the following parameters: Temperature $\left({ }^{\circ} \mathrm{C}\right)$, Conductivity $(\mu \mathrm{s} / \mathrm{cm}), \mathrm{pH}$, and dissolved oxygen (DO) (mg/L) using mercury-in-glass thermometer, conductivity meter, $\mathrm{pH}$ meter, and dissolved oxygen meter respectively.
Biochemical oxygen demand (BOD) (mg/L) was also determined by subtracting the $\mathrm{DO}$ after five days from the DO of the first day of collection. These parameters were measured pre and after the experiment. This was carried-out to ascertain the effect of leachate on the water quality.

\subsection{Histology of Liver and Gills}

C. gariepinus fingerlings were dissected and the gills, liver were extracted for histological examination as described by Kelly [18]. The gills and liver from $0 \%, 15 \%, 20 \%, 25 \%, 30 \%$, and $35 \%$ fingerlings group and control were processed, embedded with paraffin wax and sectioned with a Shandon AS 325 rotary microtomes. Thick sections of 6 microns were cut, mounted, and stained with heamatoxylin and eosin. Proper description of histological structures, appearance, and cell arrangements were achieved by slides of different organs from sections and viewed under microscope (X10, X40, X80 and X100 objectives). Microphotograph of the slides were then properly observed and interpreted.

\subsection{Statistical Analysis}

The mean mortality for the replicate of each group was computed. Analysis of variance (ANOVA) was used to test for significant difference between the physico-chemical parameters of each exposed group compared to the control at 0.05 level of significance and at their relevant degree of freedom. Also, mean and standard deviation were computed for physicochemical parameters of water for each group. Probit transformation and regression analysis were performed on the mortality data and the $\mathrm{LC}_{50}$ computed. The $95 \%$ confidence limit and intervals were also determined $[16,17]$. Predictive analytical software (PASW) version 20 was used to perform all statistical analysis.

\section{RESULTS}

\subsection{Water Quality Parameters}

Table 1 shows the physico-chemical properties of culture water contaminated with different concentrations of leachate during a 96 hours test period. Conductivity, biochemical oxygen demand $(B O D)$ and $\mathrm{pH}$ of the culture water exposed to leachates significantly varied compared to the control $(P<0.05)$, while the dissolve oxygen (DO) of the $35 \%$ leachates group significantly varied compared to the control $(P<0.05)$. 
The conductivity, $\mathrm{pH}$, and BOD increased with increasing concentration of the leachates, with the $35 \%$ leachate group having the highest values except for $\mathrm{pH}$. The DO decreased progressively with increasing leachate concentration, with the $35 \%$ group having the lowest DO values (Table 1).

Cconductivity, temperature, and BOD of the water contaminated with different leachate concentrations were all within the WHO acceptable limit for fish culture water, DO were all within the $\mathrm{WHO}$ limit except the $35 \%$ leachate group, while $\mathrm{pH}$ were all above the WHO acceptable limit for fish culture water.

\subsection{Composition of Leachates}

Table 2 summarises leachate composition from the study site and had the values of $0.10(\%)$, 0.17 (\%), 5.00 (\%), 6.20 (\%), $20.5 \mathrm{mg} / \mathrm{L}, 0.42$ $\mathrm{mg} / \mathrm{L}, 5.21 \mathrm{mg} / \mathrm{L}$, and $12.8 \mathrm{mg} / \mathrm{L}$ for total organic carbon (TOC), fatty acid, oxidase, ammonical nitrogen, iron, nickel, lead, and zinc respectively. The TOC, oxidase, iron, nickel, lead, and zinc concentration in the leachate had values above the WHO acceptable limit.

\subsection{Percentage Mortality and Survival of C. gariepinus Fingerlings Exposed to Different Concentrations of Leachates}

The percentage survival and mortality of $C$. gariepinus exposed to different concentrations of leachate is represented in Table 3. The fingerlings initial mean weight and length were $1.09 \pm 0.40 \mathrm{~g}$ and $5.17 \pm 0.66 \mathrm{~cm}$ respectively. The $C$. gariepinus fingerlings exposed to the leachate concentration of $0 \%, 15 \%, 20 \%, 25 \%$, $30 \%$, and $35 \%$ had a survival percentage of $100 \%, 90 \%, 70 \%, 60 \%, \quad 10 \%$, and $0 \%$ respectively and a mortality percentage of $0 \%$, $10 \%, 30 \%, 40 \%, 90 \%$, and $100 \%$ respectively (Table 3).

\subsection{6 hrs Probit Transformation}

Table 4 shows the summarised probit transformation mortality data for C. gariepinus exposed to different leachate concentration. The mortality data of fingerlings exposed to leachate were dependent on concentration. Erratic behavior and gasping for air due to respiratory impairment were observed on leachate exposed fingerlings.

Probit transformation of the C. gariepinus fingerlings exposed to different concentrations of leachate resulted in the regression equation of $y$ $=-11.625+3.75 X$ (Table 5). Log concentration probit regression was significant at $P<0.05$ resulting in a determination coefficient $\left(r^{2}\right)$ of 0.83 , chi-square value of 3.430 (Table 6), and a 96 hours LC $_{50}$ with $95 \%$ confidence limit of $22.5 \% \pm 0.89$ (Figure 2). The lower and upper limit of the $\mathrm{LC}_{50}$ for $C$. gariepinus fingerlings exposed to leachate were 2.077 and 5.569 respectively (Table 7 ).

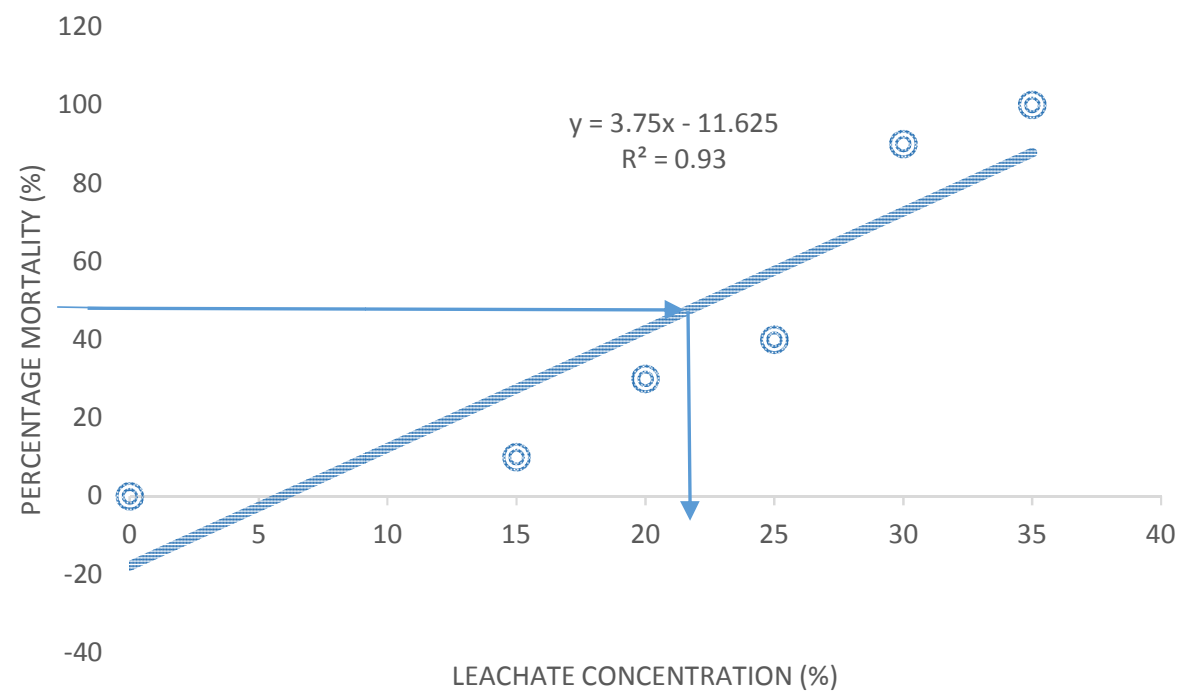

Fig. 2. Probit transformation graph of $C$. gariepinus fingerlings exposed to different Concentrations of leachate 
Udofia et al.; ARRB, 36(7): 23-37, 2021; Article no.ARRB.71258

Table 1. The 96 hrs alterations in the physico-chemical parameters of water contaminated with different concentrations of leachate

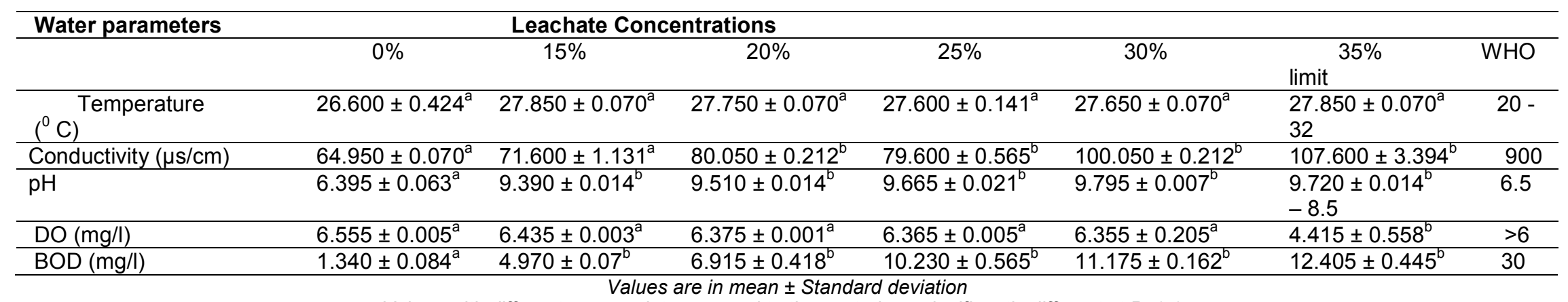

Values with different superscript compared to the control are significantly different at $P<0.05$

Table 2. Composition of leachate from lemna dump site, Calabar Municipality

\begin{tabular}{lll}
\hline Leachate Parameters & Values & WHO limit (\%) \\
\hline TOC (\%) & 0.10 & 0.15 \\
Fatty acid (\%) & 0.17 & 0.2 \\
Oxidase (\%) & 5.00 & 1.5 \\
Ammonical Nitrogen (\%) & 10 \\
Iron (mg/l) & 6.20 & 0.3 \\
Manganese (mg/l) & 20.5 & $0.05-0.5$ \\
Nickel (mg/l) & BDL & 0.07 \\
Lead (mg/l) & 0.42 & 0.05 \\
Zinc (mg/l) & 5.21 & 5.0 \\
\hline
\end{tabular}


Udofia et al.; ARRB, 36(7): 23-37, 2021; Article no.ARRB.71258

Table 3. 96 Hrs survival, percentage survival, mortality, and percentage mortality of $C$. gariepinus fingerlings exposed to different concentrations of leachate

\begin{tabular}{|c|c|c|c|c|}
\hline $\begin{array}{l}\text { Leachate } \\
\text { Concentration (\%) }\end{array}$ & Survival & $\%$ Survival & Mortality & $\%$ Mortality \\
\hline 0 & 10 & 100 & 0 & 0 \\
\hline 15 & 9 & 90 & 1 & 10 \\
\hline 20 & 7 & 70 & 3 & 30 \\
\hline 25 & 6 & 60 & 4 & 40 \\
\hline 30 & 1 & 10 & 9 & 90 \\
\hline 35 & 0 & 0 & 10 & 100 \\
\hline
\end{tabular}

Table 4. 96 Hrs Probit Transformation of mortality data of C. gariepinus fingerlings exposed to different concentration of leachate

\begin{tabular}{|c|c|c|c|c|c|c|c|c|}
\hline Conc (\%) & Log Conc (x) & $\mathbf{N}$ & $\mathbf{R}$ & $\mathbf{P}$ & $\mathbf{M}_{\mathrm{R}}$ & $\mathbf{Y}$ & $\mathbf{R}_{\mathrm{P}}$ & $P$ \\
\hline 0 & 0.00 & 10 & 0 & 0.00 & 0 & 0.00 & 0.00 & 0.00 \\
\hline 15 & 1.176 & 10 & 1 & 0.10 & 10 & 0.49 & 0.51 & 0.049 \\
\hline 20 & 1.301 & 10 & 3 & 0.30 & 30 & 2.91 & 0.09 & 0.291 \\
\hline 25 & 1.397 & 10 & 4 & 0.40 & 40 & 6.18 & -2.18 & 0.618 \\
\hline 30 & 1.477 & 10 & 9 & 0.90 & 90 & 8.41 & 0.59 & 0.841 \\
\hline 35 & 1.544 & 10 & 10 & 1.00 & 100 & 9.44 & 0.56 & 0.944 \\
\hline
\end{tabular}
regression line, $R_{P}=$ Residual probit, $P=$ Probability 
Table 5. Results of regression analysis of 96 Hrs Log Concentration-probit relationship of $C$. gariepinus fingerlings exposed to different concentrations of leachate

\begin{tabular}{llccc}
\hline $\begin{array}{l}\text { Conc. } \\
\text { (Log Unit) }\end{array}$ & $\begin{array}{l}\text { Response } \\
\text { rate, } p\end{array}$ & Equation & $\begin{array}{l}\text { Co-efficient of } \\
\text { determination, } \\
\mathrm{r}^{2}\end{array}$ & Significant level, $\alpha$ \\
\hline 0.00 & 0.00 & & & \\
1.176 & 0.10 & $\mathrm{Y}=-11.625+3.75 \mathrm{x}$ & 0.83 & 0.05 (S) \\
1.301 & 0.30 & & & \\
1.397 & 0.40 & & & \\
1.477 & 0.90 & & & \\
1.544 & 1.00 & & & \\
\hline
\end{tabular}

Table 6. Chi-square Tests of $C$. gariepinus fingerlings exposed to different concentrations of Leachate

\begin{tabular}{llll}
\hline & Chi square & df $^{\text {a }}$ & Sig. \\
\hline $\begin{array}{l}\text { PROBIT } \\
\text { Goodness-of-Fit Test }\end{array}$ & 3.430 & 3 & $0.003^{\mathrm{b}}$ \\
\hline
\end{tabular}

\subsection{Histology of C. Gariepinus Gills}

Assessment of the histological effects of different leachate concentration on $C$. gariepinus fingerlings gills after 96 hours exposure was done. The microphotograph of $C$. gariepinus (x100) gills of the control group (Plate 2a) gave a normal lamella arrangement with no significant lesion observed and the primary lamella and secondary lamella were not damaged. The primary lamellae is made up of a thin walled congested lamellar blood vessel within a sparsely populated supporting pillar cells and the secondary lamellae consists of a single layer of epithelial cells supported and separated by pillar.

The microphotograph of the $20 \%$ leachate exposed fingerlings group had almost normal arrangement of primary lamella, though had a deformed and expanded secondary lamella made up of a single layer of epithelial cells supported and separated by proliferating pillar cells. The fingerlings exposed to $25 \%$ leachate and had a disorganised arrangement of primary and secondary lamella, with the primary lamellae made up of a thin walled-narrowed-congested blood vessel (Plate 2c microphotograph). The arrangement of the secondary lamella was in a disorganised pattern with a single layer of epithelial cells, proliferating pillar cells, and congested blood vessels. The microphotograph of the gills of C. gariepinus (x100) of the $(30 \%$ and $35 \%$ leachate) leachate group (plate $2 \mathrm{~d}$ and 2e) showed an intact cartilaginous frame for primary and secondary lamellae. The primary lamellae consists of thin walled narrowed congested blood vessel with thrombosis, scanty pillar cells, and the secondary lamellae made up of a single layer of epithelial cells with poor cytoplasmic outline, scanty supporting pillar cells.

\subsection{Histology of C. gariepinus Liver}

The histotology on the liver of $C$. gariepinus fingerlings of the different leachate exposure groups were examined. Plate $3 a$ (control group) microphotograph of the liver of $C$. gariepinus (x100) showed normal liver arrangement, having an irregular arranged cords of hepatocytes and separated by vascular channels. The hepatocytes showed deeply stained nuclei with moderate cytoplasm and had a congested central blood vessels and vascular channel.

The fingerlings of the $20 \%$ exposed leachates group showed disorganized cords of hepatocytes and central congested blood vessels. The hepatocytes had irregular vacuolated cytoplasm. There was vascular dilation and congestion. The $25 \%$ and $30 \%$ leachate group containing the exposed fingerlings showed a disorganized cords of hepatocytes with poor cytoplasmic and nuclei outline, with their central blood vessels and vascular channels dilated and congested. The microphotograph of the liver of $C$. gariepinus $(x 100)$ revealed hepatocyte arranged in a disorganised pattern. The hepatocytes were swollen with poor outline having pyknotic nuclei. The vascular channels are markedly distended and congested. 
Table 7. $\mathrm{LC}_{50}$ with $95 \%$ confidence limits of C. gariepinus fingerlings exposed to leachate concentrations

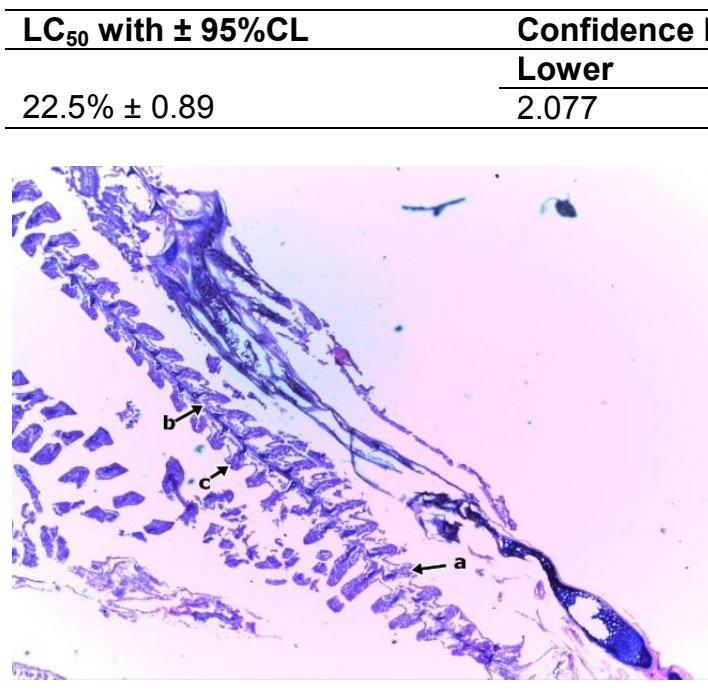

B. $20 \%$ Leachate

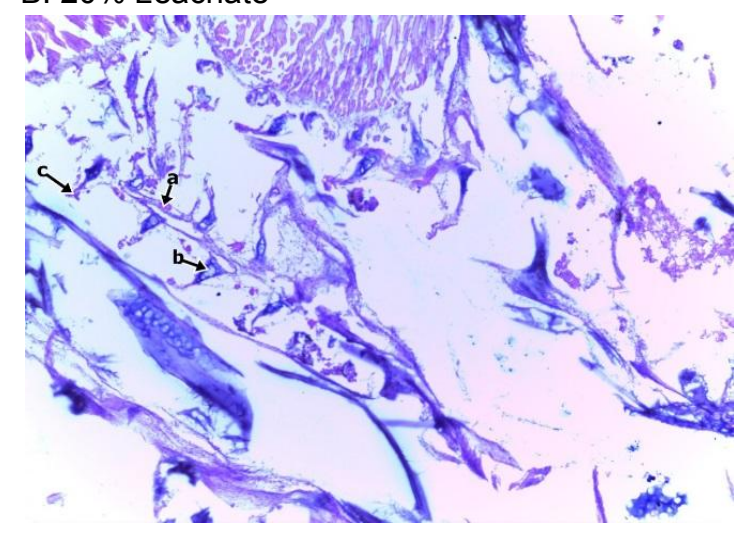

C. $25 \%$ Leachate

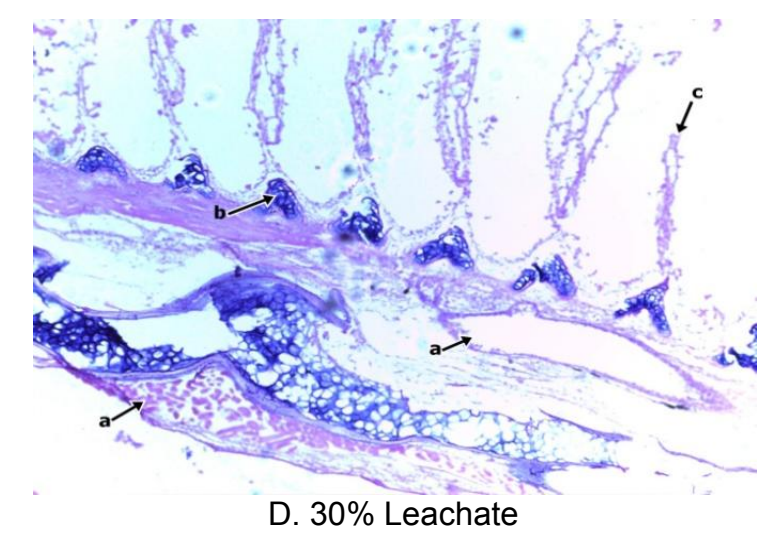

D. $30 \%$ Leachate

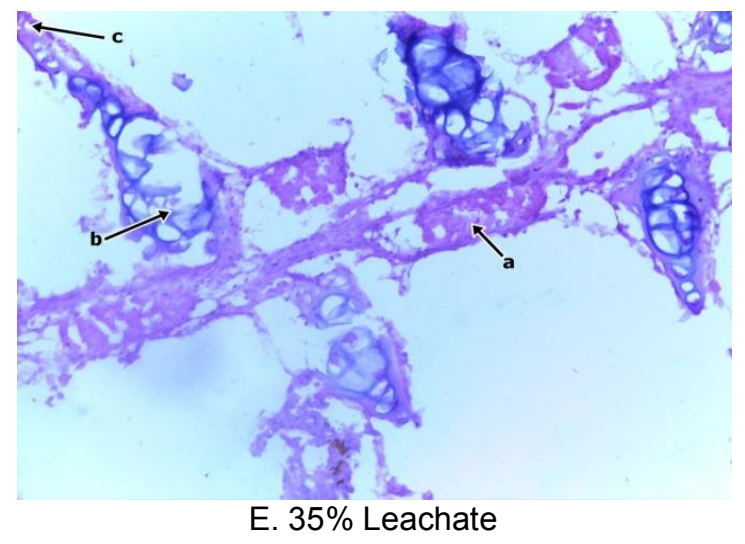

Plate 2a-2e. Microphotograph of the gill tissues showing histopathological changes at different concentrations of leachate on C. gariepinus (X100 magnification)

(a- Lamellar Artery, B-Primary Lamella, C-Secondary Lamella). 


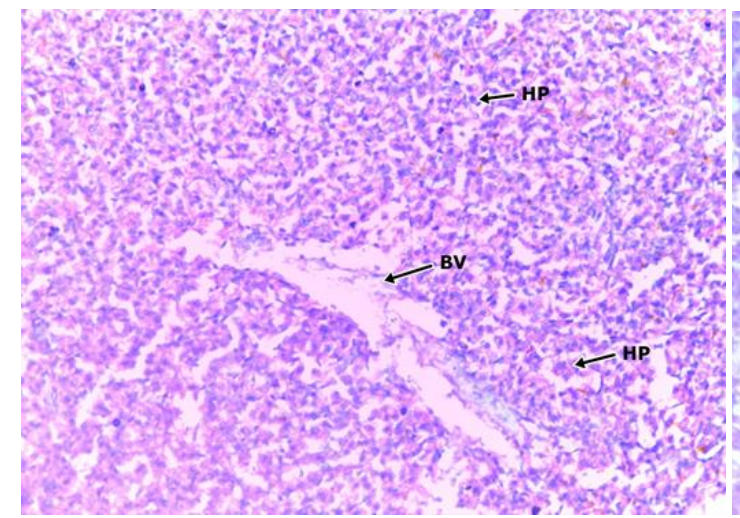

A. Control Group

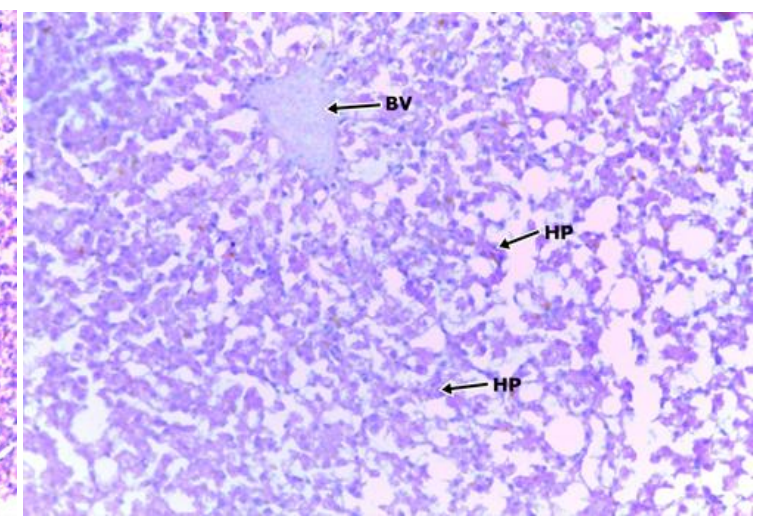

B. $20 \%$ Leachate

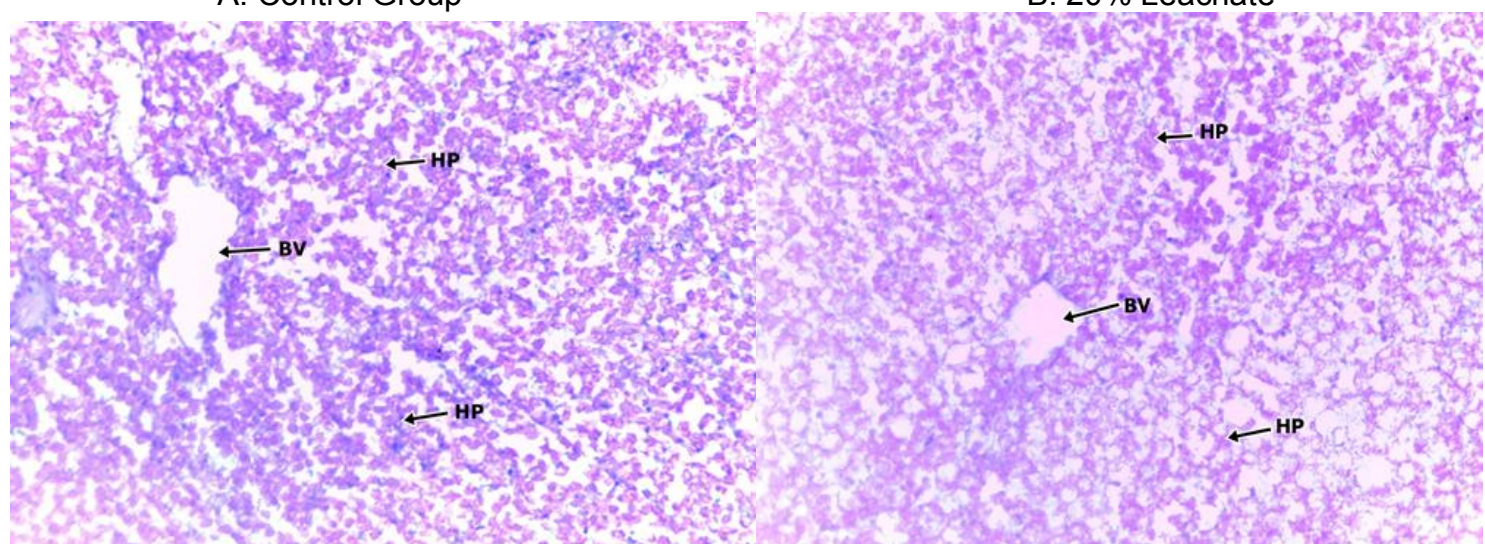

C. $25 \%$ Leachate D. $30 \%$ Leachate

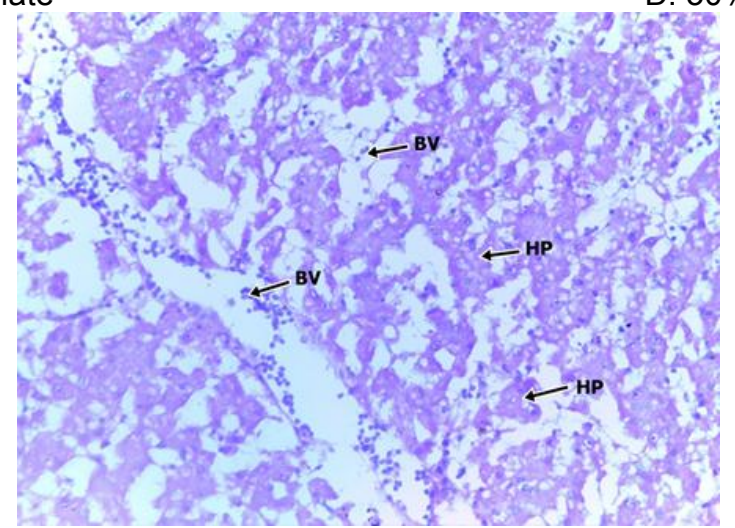

\section{E. 35\% Leachate}

Plate 3a-3e. Microphotograph of the liver tissues showing histopathological changes at different concentrations of leachate on C. gariepinus (X100 magnification) (HP-hepatocytes, CV or BV-blood vessel)

\section{DISCUSSION}

According to Christensen [1], leachate is any liquid that on flowing over matter, draw out solutes, suspended solids, and other material components, thereby introducing deleterious substances into the environment. The introduction of leachate into any environment may introduce hazardous materials into the environment which can portend a threat to the survival of living organisms including human [19].

Turbidity of water bodies can increase with the introduction of contaminants such as leachate, thereby inhibiting light penetration, and subsequently reducing photosynthesis and 
biological productivity [20]. The levels of TOC, oxidase, iron, nickel, lead, and Zinc were above the WHO limit, and were therefore termed as being contaminated. This led to the mortality and alterations in the gills and liver of $C$. garipinus fingerlings. This study disclosed the variations and elevation in the water quality parameters of the culture water of various concentrations of leachate except $\mathrm{DO}$, and this was in conformity with the results gotten by Nwabueze [21]. Temperature, conductivity, $\mathrm{pH}$, and $\mathrm{BOD}$ in water increased with increasing leachate concentrations except in few cases, but DO reduced with increasing leachate concentration. Generally, temperature, conductivity, $\mathrm{pH}$, and BOD had higher values, while dissolved oxygen had lower values in the aquarium contaminated with the highest concentration of leachate $(35 \%$ leachate) compared to the control. Adeboyejo et al. [22] presented similar findings when researching on the acute toxicity of industrial effluents from Agbara environs of Ologe lagoon on early life stages of $C$. gariepinus. The increase in microbial activities could be due to the leachate introduction [23]. The increase in leachate concentration, increased the alkalinity $(\mathrm{pH})$ of water in the aquarium, thereby increasing the level of microbial activities. This potentially caused the reduction in the DO level and the increase in the BOD level, because more DO are utilized by microbes for various microbial activities to meet the higher oxygen demands (BOD) of microbes. Similarly, the leachates potentially increased the conductivity level of the culture water. Adeboyejo et al. [22] reported a higher mean temperature value in water exposed to $20 \%$ industrial effluents compared to the present study, and this maybe as a result of the difference in the toxicants, geographical area air temperature, length of formation of the effluents, and differences in composition of test toxicant. The mean temperature and biochemical oxygen demand of water contaminated with the highest concentration of leachate in the present study was lower, while the $\mathrm{DO}$ and $\mathrm{pH}$ for the highest concentration of leachate was higher than the findings of Nwabueze and Ekelemu [23]. The difference in the results of the compared studies maybe as a result of the differences in landfills, waste composition, waste age, leachate composition, and landfilling technology [5].

Resistance to diseases may increase due to clogging of fish gills, thereby, lowering growth rate, and inhibiting the egg and larval developments [23]. Toxicity assessment with bioassay method has been commonly used to assay landfill leachate toxicity. This method has been used to determine the adverse effect of organisms exposed to contaminants. [8]. Toxicity assessment using bioassay can represent either acute or chronic exposure [24]. This study on the toxicity of Lemna leachate on C. gariepinus fingerlings was concentration dependent, and conformed to the findings of Andem et al. [25], Joseph et al. [26], and Otong et al. [27]. C. gariepinus fingerlings exposed to different concentrations of leachate showed signs of stress, erratic behaviour, jerky movement, rapid opercular movement, leaping out of water, thick mucus, and gasping for air when exposed to different concentrations of leachates. These behaviours were due to respiratory inefficiencies, and this aligned with the findings of Adeboyejo et al. [22] and Pathan et al. [28]. C. gariepinus fingerlings appeared darker in the first $24 \mathrm{hrs}$ exposure, and this was in consonance with Adeboyejo et al. [22] observations.

In the $25 \%$ leachate group, $40 \%$ fingerlings mortality was recorded. The $35 \%$ leachate group recorded $100 \%$ mortality, and this were considerably higher than the findings of Adeola et al. [29] and Oshode et al. [30] for similar leachate concentration. The dissimilarities in the mortality rates of the test fingerlings for the studies compared maybe as a result of differences in leachate contents, dump site age, fish species, and fingerlings age. Furthermore, the response of fish to various metal and organic contaminants are transient and dependent on species, enzymes, and single or mixed contaminants [31].

In the present study, the 96 hrs LC $_{50}$ with $95 \%$ confidence limit for $C$. gariepinus exposed to different concentrations of leachate was $22.5 \% \pm$ 0.89 , and this relatively low value shows that Lemna dump site leachate is extremely toxic. This high toxicity of the leachates possibly led to the mortality of the fish fingerlings due to stress and endocrinal disruption of the fingerlings cells. The study of Adeboyejo et al. [22] and Oshode et al. [30] on the eco-toxicological assessment using $C$. gariepinus recorded higher $\mathrm{LC}_{50}$ value than that of this study. Contrary to this, the $\mathrm{LC}_{50}$ value of the present study was higher than that reported by Pathan et al. [28] for a study on the toxicity and behavioural changes in Rasbora daniconius exposed to lethal concentrations of paper mill effluents. The differences in the 96 hours $L^{2} C_{50}$ value of the different study maybe as a result differences in composition of leachate, toxicant, age of dump site, fish species, and age 
of fingerlings used. It could also be because the response of fish to variety of metal and organic pollutants are transient and are dependent on species, enzymes, and single or mixed contaminants [31].

Studies on the histological alterations in gills, liver, gonads, and other organs of fish have become an important bio-indicator of the toxic effects of pollutants [32]. The different concentration of leachates showed significant influence on the histology of $C$. gariepinus fingerlings tissues. C. gariepinus gills and liver showed histological alterations, and was similar to the findings of Aderemi et al. [33] who presented some degree of histological changes in the liver of contaminated fishes.

The gills of the exposed fingerlings were altered. The $20 \%$ leachates group showed deformed and expanded secondary lamella made up of a single layer of epithelial cells supported and separated by proliferating pillar cells. The $25 \%$ leachates group had an irregular orientation of secondary and primary lamella, with primary lamellae consisting of thin walled-narrowed congested blood vessel. The secondary lamellae were arranged in an irregular pattern consisting of proliferating pillar cells, single layer of epithelial cells, and congested blood vessels. The gills of $30 \%$ and $35 \%$ leachate group had secondary and primary lamellae with cartilage frame intact. The primary lamellae consists of a narrowed and congested thin-walled blood vessel with scanty pillar cells, thrombosis and the secondary lamellae comprising scanty supporting pillar cells, and a single layer of epithelial cells with poor cytoplasmic outline,. These research shows significant alterations from a normal arrangement of gills. Adeboyejo et al. [22], Pathan et al. [34], and Oshode et al. [30] reported similar findings.

The $20 \%$ leachate group of dead fingerlings had disoriented cords of hepatocytes and a congested central blood vessels. The hepatocytes had disorganised vascular dilation, vacuolated cytoplasm, and congestion. The $25 \%$ and $30 \%$ leachates group had disorganized cords of hepatocytes with poor nuclei and cytoplasmic outline. The vascular channels and the central blood vessels were congested and dilated. The $35 \%$, leachate group showed altered liver of C. gariepinus liver and had hepatocyte cords arranged in an irregular pattern. The hepatocytes were swollen and had poor outline having vascular channels and pyknotic nuclei markedly congested and distended, thus agreeing with the results of Adeboyejo et al. [22] and Aderemi et al. [33].

\section{CONCLUSION}

The leachates altered the water quality parameters of the culture water when compared to the control, thereby increasing the $\mathrm{pH}$, conductivity, temperature, and BOD while also decreasing the DO. Leachates induced stress on the fingerlings, thereby causing the mortality of fingerlings and alterations in the organisation of the gills and liver of fingerlings. The toxicological effects was concentration dependent. The relatively low $L_{50}$ value of the leachate on $C$. gariepinus fingerlings indicates high toxicity of the leachates on the fingerlings.

\section{CONSENT}

It is not applicable.

\section{ETHICAL APPROVAL}

The authors ensured that all ethical and other basic principles underlying behavior and advancing welfare for the use of animals in research, including handling, relevant laws and regulations were considered before proceeding with the research. Permission was also received from the relevant bodies for the use of fish for this experiment.

\section{COMPETING INTERESTS}

Authors have declared that no competing interests exist.

\section{REFERENCES}

1. Christensen $\mathrm{TH}$, Kjeldsen $\mathrm{P}$, Bjerg $\mathrm{PL}$, Jensen DJ, Christensen JB, Baun A, Albrechtsen $\mathrm{H}$, Herom G. Biochemistry of Landfill leachate plumes. Appl. Geochem. 2001;16: 659-665.

2. Mor S, Ravindra K, Dahiya RP, Chandra A. Leachate characterization and assessment of Groundwater pollution near Municipal Solid Waste Landfill Site. Environ. Monitor. Assess. 2006;4:325-334.

3. Kulikowska D, Klimiuk E. The effect of Landfill age on municipal Leachate composition. Bioresour. technol. 2008;99 (13):5981-5985.

4. Zin M, Shaylinda N, Abdul Aziz H, Adlan $M$, Ariffin A. Characterization of Leachate at Matang Landfill site, Perak, Malaysia. Acad. J. Sci. 2012;1(2): 317-322. 
5. Kjeldsen $P$, Barlaz M, Rooker A, Baun J, Ledin A, Christensen T. Present and longterm composition of MSW Landfill Leachate: A review. Crit. rev. Environ. Sci. Technol. 2002;32 (4):297-336.

6. Bhambulkar A. Effects of Leachate recirculation on a Landfill. Int. J. Adv. Eng. Sci. Technol. 2011;11 (2):286 - 291.

7. Ojolo SJ, Bamgboye Al, Aiyedun PO, Ogunyemi AP. Pyrolysis of shredded plastic waste. In: proceedings of the 7 th Africa-America International conference on manufacturing technology, Port-Harcourt, Nigeria. 2004;1:412-518.

8. Thomas D, Tyrrel S, Smith R, Farrow S. Bioassays for the evaluation of Landfill Leachate toxicity. J. Toxicol. Environ. Health. 2009;12 (1):83-105.

9. Bortolotto $\mathrm{T}$, Bertoldo J, Silveira $\mathrm{F}$, Defaveri T, Silvano J, Pich C. Evaluation of the toxic and genotoxic potential of Landfill Leachates using bioassays. Environ. toxicol. pharm. 2009;28 (2):288-293.

10. Christie WW and Han X. Lipid analysisisolation, separation, identification and lipidomic analysis (4 $4^{\text {th }}$ edition). Oily press, Bridgwater, U.K. 2010;446.

11. Phanis $P$, Sumantakul $T$, Wongpakdee $\mathrm{W}$, Fukana N, Ratanawimarnwong J, Sitanurak D, Nacapricha D. Anal. Chem. 2016;88:8749 - 8756.

12. Trinder $P$. Determination of glucose in blood using glucose oxidase with an alternative oxygen acceptor. Ann. Clin. Biochem. 1966;6:24 - 32 .

13. Whiteside PJ, Milner BA. Pye Unicam Atomic Absorption Data Book, 6th ed., Pye Unicam Limited, Cambridge, England. $1984 ; 72$.

14. Rahman MZ, Hossain Z, Mullah MFR, Ahmed GU. Effects of diazinon 60EC on Anabus testudineus, Channa punctatus and Barbades gomonotus. The ICLARMS Quarterly, 2002;25:8- 11.

15. Sprague JB. The ABC's of pollutant bioassay using Fish. A Paper presented on Environment monitory in Los Angeles, California. 1972; June 27 - 28 (ASTM).

16. Finney DJ. Statistical Methods in Biological Assay. (3rd Edition), London, Charles Griffinco, 1971;508.

17. Mather K. Statistical Analysis in Biology. London, Chapman and Hall, 1973; 420pp.

18. Kelly WR. Veterinary Clinical Diagnosis. (2nd edition). London, Balliere Tindall. $1979 ; 360$.
19. Alimba CG. DNA and systemic damage induced by Landfill Leachates and health impacts of Human exposure to Landfills in Lagos and Ibadan, Nigeria. Ph.D Thesis, Department of Zoology, University of Ibadan, Nigeria. 2013;258.

20. Pillay TVR. Environmental impacts of Cage-culture for Catfish in Chau Doc, Vietnam. Aquaculture colloborative Research support program. Blackwell scientific Publications inc., Cambrigde, England, 1992;82.

21. Nwabueze AA. Water quality and Microorganisms of Leachate-contaminated Pond. American J. Scient. Indust. Resear.. 2011;2(2):205-208.

22. Adeboyejo OA, Fagbenro OA, Adeparusi $\mathrm{EO}$, Clarke EO. Acute toxicity of industrial effluents from Agbara environs of Ologe Lagoon on early life stages of African Catfish Clarias gariepinus. American J. of Resear. Commun. 2013;1(3):50-60.

23. Nwabueze AA, Ekelemu JK. Growth and survival of Clarias gariepinus (Burchell, 1822) Fingerlings in different concentrations of domestic Leachate. J. Agric. Biol. Sci. 2001;6(5):25-29.

24. Singh V, Mittal A, Sinna V. Toxicity analysis and public health aspects of Municipal Landfill Leachate: A case study of Okhla Landfill, Delhi', 2011;(18):18.

25. Andem AB, Ibor OR, Joseph AP, Eyo VO, Edet AA. Toxicological evaluation and histopathological changes of synthetic Pyrethroid Pesticide (Cypermethrin) exposed to African Clariid Mud Cat Fish (Clarias gariepinus) Fingerlings. Int. J. Toxicol. Pharm. resear., 2016;8(5):360 367.

26. Joseph AP, Otong BE, Okoro FT, Akpan OE. Toxicological Responses of African Mud Catfish (Clarias gariepinus; Burchell, 1822) Fingerlings Exposed to Culture Water Contaminated with different Concentrations of Cypermethrin. Advan. Resear. 2018;17(4):1-15.

27. Otong BE, Joseph AP, Okoro FT. Water Quality Contamination and Mortality of African Mud Catfish (clarias gariepinus; burchell, 1822) Fingerlings exposed to Paint Effluents. Asian J. Environ. Ecol. 2018;7(3):1-12.

28. Pathan TS, Sonawane DL, Khillare YK. Toxicity and behavioural changes in Freshwater Fish Rasbora daniconius exposed to Paper Mill Effluent. J. biotech. Resear. Int, 2009;2(4):263-266. 
29. Adeola AO, Amusat TH, Peijun L. Toxicity of Leachates from the Aba-Eku Landfill Leachate Lagoon, Ibadan, South-Western Nigeria. Adv. Appli. Sci. Resear. 2011;2 (2):450-460.

30. Oshode OA, Bakare AA, Adeogun AO, Efuntoye $M O$, Sowunmi AA. Ecotoxicological assessment using Clarias gariepinus and microbial characterization of Leachate from Municipal Solid Waste Landfill. Int. J. Environ. Resear., 2008; 2(4):391-400.

31. Pavlović SZ, Mitić SSB, Radovanović TB, Perendija BR, Despotović SG, Gavrić JP, Saicić ZS. Seasonal variations of the activity of Antioxidants defense Enzymes in the Red Mullet (Mullus barbatus) from Adriatic Sea. Marine Drugs. 2010;8(3): 413-428.
32. Gupta SK, Pal AK, Sahu NP, Saharan N, Mandal SC, Chandraprakash AMS, Prusty AK. Dietary microbial levan ameliorates stress and augments immunity in Cyprinus Carpio Fry (Linnaeus, 1758) exposed to sub-lethal toxicity of Fipronil. Aquac. Resear. 2012;11 - 20.

33. Aderemi AO, Adewumi GA, Adebayo A., Otitoloju AA. Municipal Landfill Leachate characterization and its induction of glycogen vacuolation in the Liver of Clarias gariepinus. Inter. J. Environ. Protect. 2012; (4):20-24.

34. Pathan TS, Thate PB, Shinde SE, Sonawane DL. Histopathological effects of Paper Mill Effluent in Liver and Kidney of a Fresh Water Fish, Rasbora daniconius. Resear. J. Bio. Sci. 2010;5(5):389-394.

(c) 2021 Udofia et al.; This is an Open Access article distributed under the terms of the Creative Commons Attribution License (http://creativecommons.org/licenses/by/4.0), which permits unrestricted use, distribution, and reproduction in any medium, provided the original work is properly cited.

Peer-review history:

The peer review history for this paper can be accessed here: https://www.sdiarticle4.com/review-history/71258 